\title{
Compassion practice, evolutionary advantage, and social resilience: the triad worth SEPR community's attention
}

\author{
Wei-Ning Xiang ${ }^{1}$
}

Accepted: 20 August 2021 / Published online: 20 September 2021

(c) The Author(s), under exclusive licence to Springer Nature Singapore Pte Ltd. 2021

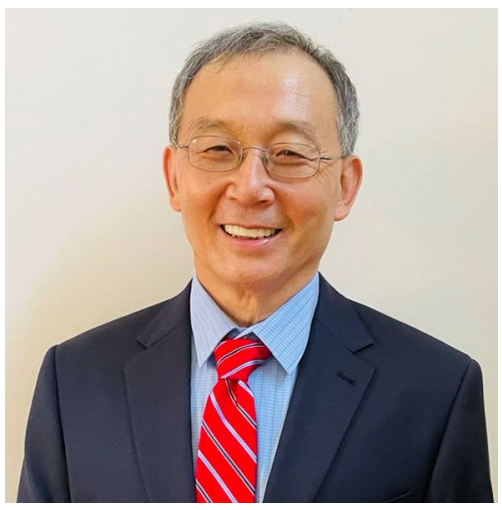

Wei-Ning Xiang is a professor of geography and earth sciences at the University of North Carolina at Charlotte, USA; he is the founding editor in chief of SEPR.

By now, the COVID-19 pandemic has been around for over 20 months. What has it shown to the world which we the socio-ecological practice research (SEPR) community should take notice of and, better yet, can dig into for insight?

First, it is a recurring global common threat and super wicked problem.

If the COVID-19 pandemic has ever shown anything about itself that is beyond a shadow of a doubt, it is that the pandemic has a dual identity inherited from the 1918 influenza pandemic, nicknamed "the mother of all pandemics" by American virologists David Morens and Jeffery Taubenberger (Morens \& Taubenberger 2018, p.1449). That is, it is a global common threat to which no human being on the

Wei-Ning Xiang

wxiang@uncc.edu

1 University of North Carolina At Charlotte, Charlotte, NC, USA earth is immune; and a super wicked problem to which a solution of any kind creates new and often worse problems. ${ }^{1}$

Exhibiting this infamous ancestral identity to its fullest extent, the COVID-19 pandemic has been doing exactly, if not more aggressively, what its ancestor did notoriously over a century ago. Since late 2019, it has dealt a punishing, devastating blow indiscriminately to human life in every corner of the world and triggered globally a tsunami of mutually exacerbating catastrophes. Once again, it has turned the global village upside down into a distrusting, fearful swamp where "a [public] health crisis became an economic crisis, a food crisis, a housing crisis, a political crisis. Everything collided with everything else." (Bill and Melinda Gates Foundation 2020, p.4). ${ }^{2}$

Second, suffering is a shared human experience; compassion practice promotes survival and well-being.

If the COVID-19 pandemic has ever proven anything about us, Homo sapiens, which is also beyond a shadow of a doubt, it is the same dual reality our ancestors experienced

\footnotetext{
1 [1] The characteristic of wicked problems, "proposed 'solutions' often turn out to be worse than the symptoms" (Churchman 1967, p.B-141), can be described with a medical term iatrogenic in that solutions to an existing problem will almost inevitably induce new, equally if not more wicked problems that could be well beyond people's imaginations (Xiang 2021a, p.76). For definition of iatrogenic, see Collins English Dictionary (2020). [2] For a summary on "wicked problems and tame problems", see Xiang (2021a, pp.76-77); for the origin of the conceptions, see Churchman (1967) and Skaburskis (2008); for a recent literature review, see Termeer et al. (2019). [3] A common threat is a danger-something or someone that can hurt or harm people - that may happen to every individual human being in a certain place (e.g., the earth, a country, a region, a city, a village, or a community) to the extent that no one in that place is immune; a common threat can come from a natural disaster, a human conflict, or a combination of both (Palko \& Xiang 2020, p.260; Xiang 2020, p.200). Some choose to use "collective threat" in lieu of "comment threat" with comparable meaning [e.g., Gelfand (2021); Gelfand et al. (2021)].

2 Throughout the essay, parentheses in direct quotations are added by the author for clarity unless noted otherwise.
} 
during the 1918 pandemic. That is, in the presence of such vicious global common threat and super wicked problem, suffering is a shared human experience from which no one is exempt, and practicing compassion is both a moral behavior and an effective strategy for human survival and well-being.

This time, like our ancestors in the 1918 pandemic, all of us are involuntarily on the virus' blacklist, and to a varying extent, we are all victims of, inter alia, the related sickness, loss of loved ones, fear, loneliness, depression, economic hardships, domestic violence, deepened poverty, social unrest, and political turmoil. But at the same time, we are also witnesses and beneficiaries of numerous instances of compassion practice, in which people helped those, including total strangers, who were in danger or distress, even if doing so could incur a risk to their own lives and/or well-being. ${ }^{3}$ The compassionate acts people took, whether donating personal protective equipment (PPE) and vaccines, ${ }^{4}$ volunteering at hospitals and nursing homes in the hardest-hit cities (e.g., Wuhan, China and New York City, the USA), or just observing social distancing and self-isolation rules, getting fully vaccinated, and wearing mask, helped save lives and assuage the suffering of others. Compassion practice has been borne out once more to be what British naturalist Charles Darwin (1809-1882) proposed 150 years ago-a moral behavior and an effective strategy for human survival and well-being that may confer an evolutionary advantage to communities and societies.

In his 1871 book The descent of man, and selection in relation to sex, "Darwin proposed that natural selection would favor the occurrence of compassion," writes American psychologist Paul Ekman in a 2010 essay entitled Darwin's compassionate view of human nature (Ekman 2010, p.557).

According to Paul Ekman, in the fourth chapter of this "greatest unread book, ... Darwin explained the origin of what he called sympathy (which today would be termed empathy, altruism, or compassion-sic), describing how humans and other animals come to the aid of others in distress. ... (H)e wrote that the highest moral achievement is

\footnotetext{
${ }^{3}$ [1] Compassion and compassion practice are related yet distinct constructs (Chen \& Xiang 2020, pp.338-341). Compassion is an affective and motivational thought of a human being about the wellbeing of other human beings or even all sentient beings. It comprises a dual mental state: a sympathetic emotion about the suffering of another individual or group; and a concomitant desire to help assuage the suffering for the welfare of that individual or group. Compassion practice is a mental-behavioral process in which one reaches the dual mental state through meditation or contemplation; and fulfills the desire to help through actions (Ibid., p.338). [2] For a useful comparison of compassion with other related yet distinct constructs of altruism, compassionate love, empathy, pity, and sympathy, see Jimenez (2009, pp. 210-211); for the relationship between compassion and self-compassion, see Chen \& Xiang (2020, p. 339).

${ }^{4}$ Personal protective equipment (PPE) is specialized clothing or equipment, worn by a healthcare worker for protection against infectious materials. It includes gloves, gowns/aprons, masks and respirators, respirators, goggles, and face shields (CDC 2004).
}

concern for the welfare of all living beings, human and nonhuman." (Ibid.) Darwin then proposed that in this capacity, compassion practice confers an evolutionary advantage to communities where compassion is widely practiced:

In however complex a manner this feeling [of sympathy, or compassion-see Ekman's note in the above quote] may have originated, as it is one of high importance to all those animals which aid and defend one another, it will have been increased through natural selection; for those communities, which included the greatest number of the most sympathetic [i.e., compassionate] members, would flourish best, and rear the greatest number of offspring (Darwin 1871/2004, p.130; italics by the author of this essay).

It is noteworthy that even though this facet of Darwin's thinking about compassion practice and human evolution is unknown to many (Ekman 2010, p.557), some scholars have followed his line of reasoning inadvertently and proposed comparable ideas. ${ }^{5}$

The evolutionary advantage compassion practice confers to communities and societies is an essential part of their collective ability to effectively cope with the vicissitudes of the surrounding world. Throughout human history, it is this ability that has enabled many communities and societies to overcome extreme difficulties and survive unpredictable vicissitudes of nature and life. This ability is codified by contemporary scholars as social resilience, a nomenclature rooted in the 1973 seminal work of Canadian ecologist Crawford Holling (1930-2019) (Holling 1973). ${ }^{6}$

\footnotetext{
${ }^{5}$ For a recent example, American scholar Michael Garstang generalizes in his 2015 book that for all sentient beings, evolutionarily moral behaviors are those that promote survival (Garstang 2015, p.x). In Elephant sense and sensibility: behavior and cognition, he writes, drawing on a lifelong research on African elephants, "Even though value is seen as a human creation, made both possible and necessary by human rationality, the basis for moral behavior rests upon behavior that promoted survival. Elements of such behavior are present in all species ..." (Ibid.; italics by the author of this essay).

${ }^{6}$ [1] For definitions of social resilience, see Adger (2000), Keck \& Sakdapolrak (2013), and Kwok et al. (2016). For reviews about the art and science of resilience, see Beller et al. (2018), Biggs et al. (2015), Folke et al. (2021), Gunderson (2000), Meerow et al. (2016), Romero-Lankao et al. (2016), and Wu \& Wu (2013), among others. [2] As human communities and societies are dependent on ecological systems for their livelihoods and human activities have increasingly significant impacts on ecosystems [Daily 1997; Millennium Ecosystem Assessment (MA), 2005], social resilience is closely connected with ecological resilience-the ability of natural ecosystems to sustain themselves in the face of disturbance (Adger 2000). In the literature, some use social-ecological resilience - "the resilience of socialecological systems" (Folke et al. 2021, p.1774; Gret-Regamey et al. 2019, p.290) - to highlight this connection [e.g., Folke et al. (2021, p.1776)]. [3] In this essay, the choice of using social resilience in lieu of social-ecological resilience was made deliberately for a more streamlined and focused discussion.
} 
Compassion practice as such becomes a way to build social resilience through the evolutionary advantage it confers. At the risk of oversimplification, the nexus between compassion practice, evolutionary advantage, and social resilience can be expressed as follows:

The greater the number of compassionate members in a community or society, the bigger the evolutionary advantage their compassion practice would confer, and the more resilient the community or society could become; and vice versa.

In a recent essay with a provocative title Resilience: now more than ever, Swedish resilience scholar Carl Folke and coauthor colleagues advocate "nurturing resilience" as a strategy to seize the window of opportunity the COVID19 pandemic provides for making major systemic transformational changes in the human society (Folke et al. 2021, pp.1175-1176). They write,

Clearly, nurturing resilience is of great significance in such systemic transformational change towards sustainable futures and requires collective action on multiple fronts, action that is already being tested by increasing turbulence incurred by seemingly unrelated shocks (Ibid., p.1176; italics by the author of this essay).

Compassion practice is certainly well-qualified as one such collective action. As articulated earlier in this essay, not only is it "already being tested by" the COVID-19 pandemic and continuously going strong, but it has also passed many tests of "turbulence" throughout human history, including the one over 100 years ago by "the mother of all pandemics."

For the SEPR community, there is a triad of social responsibilities coming along with the triad of compassion practice, evolutionary advantage, and social resilience. These are:

1. practicing compassion in life and work to nurture social resilience in communities and societies;

2. advocating the nexus between compassion practice, evolutionary advantage, and social resilience; and

3. publicizing exemplary instances of compassion practice in the history of socio-ecological practice. ${ }^{7}$

\footnotetext{
7 [1] In fact, many have already acted on this triad and, through SEPR, some shared their experience and convictions. Examples of (1) practicing compassion in life and work include Chen \& Yuan (2020), Douglas (2020a-b), and Wang (2020); (2) advocating the nexus include Forester \& McKibbon (2020), Hu (2020), Palko \& Xiang (2020), and Zheng (2020); and Chen \& Xiang (2020) is an example of (3) publicizing exemplary instances of compassion practice in socio-ecological practice. [2] Advocating compassion practice in the academy is not new. See, for example, Lyles \& White (2019), Lyles et al. (2018), and Tsui (2013).
}

Fulfilling this triad of responsibilities will enable the SEPR community to better serve the ultimate purpose of socio-ecological practice- - "to bring about a secure, harmonious, and sustainable socio-ecological condition serving human beings' need for survival, development, and flourishing." (Xiang 2019a, p.7) The knowledge the community members generate while fulfilling one or any combination of the three responsibilities will contribute to the scholarship of ecopracticology - the study of socio-ecological practice. Therefore, both the process and outcome of this worthy endeavor should be archived and publicized through the community's flagship journal Socio-Ecological Practice Research ${ }^{8}$ As the editor, I pledge that they will, and hereby invite all members of the SEPR community to participate and contribute.

Acknowledgements Some contents of this essay (from the $2^{\text {nd }}$ to $7^{\text {th }}$ paragraph) are based on a blog of mine written for Springer Nature's "SDG 11 Sustainable Cities and Communities" (Xiang 2021b). I thank my publisher Xiaoli Pei at Springer Nature for inviting me to write the blog and encouraging its use in this essay. I thank my students at the University of North Carolina at Charlotte (UNC Charlotte), USA, for getting the digital copies of Garstang's 2015 book: Tiangyang Chen, Veronica Horvath, and Hannah Palko. I appreciate helpful hints Reese Manceaux at the J. Murrey Atkin Library at UNC Charlotte offered for getting the fourth chapter of Darwin's book.

\section{References}

Adger WN (2000) Social and ecological resilience: are they related? Prog Hum Geogr 24(3):347-364

Beller EE, Spotswood EN, Robinson AH et al (2018) Building ecological resilience in highly modified landscapes. Bioscience 69(1):80-92

Biggs R, Schluter M, Schoon ML (eds) (2015) Principles for building resilience: sustaining ecosystem services in social-ecological systems. The Cambridge University Press, Cambridge

Bill \& Melinda Gates Foundation (2020) COVID-19: a global perspective. 2020 Goalkeepers Report, September 14, 2020. https://www. gatesfoundation.org/goalkeepers/report/2020-report/\#GlobalPers pective. Accessed 15 Sept 2020

CDC (The United States Centers for Disease Control and Prevention) (2004) Guidance for the selection and use of personal protective equipment (PPE) in healthcare settings. https://www.cdc.gov/hai/ pdfs/ppe/ppeslides6-29-04.pdf. Accessed 13 Aug 2021

Chen Y, Xiang W-N (2020) Why was tao lujia so willing and swift to greenlight the red flag canal project in 1960? new insights via a lens of compassion practice. Socio Ecol Pract Res 2(4):337-346. https://doi.org/10.1007/s42532-020-00061-4

Chen L, Yuan X (2020) China's ongoing battle against the coronavirus: why did the lockdown strategy work well? Scio Ecol Pract Res 2(2):175-180. https://doi.org/10.1007/s42532-020-00048-1

Churchman CW (1967) Wicked problems. Manage Sci 14(4):B141-B142

\footnotetext{
${ }^{8}$ For an introduction to the emerging field ecopracticology, see Xiang (2019a); for an overview of the journal, including its 11 article types, see Xiang (2019b).
} 
Collins English Dictionary (2020) Iatrogenic. Collins English Dictionary. https://www.collinsdictionary.com/dictionary/english/iatro genic. Accessed 22 Dec 2020

Daily GC (1997) Introduction: what are ecosystem services? In: Daily GC (1997) Nature's services: societal dependence on natural ecosystems. 1-10. Island Press, Washington, DC

Darwin C (1871/2004) The descent of man, and selection in relation to sex. In: Moore J, Desmond A (eds) (2004) The descent of man, and selection in relation to sex. Penguin, New York

Douglas I (2020a) Scholar in the SEPR spotlight: Ian Douglas. Socio Ecol Pract Res 2(2):185-197. https://doi.org/10.1007/ s42532-020-00051-6

Douglas I (2020b) COVID-19 compassion in self-isolating old age: looking forward from family to regional and global concerns. Socio Ecol Pract Res 2(3):229-235. https://doi.org/10.1007/ s42532-020-00053-4

Ekman P (2010) Darwin's compassionate view of human nature. Journal of American Medical Association 303(6):557-558

Folke C, Carpenter C, Elmqvist T et al (2021) Resilience: now more than ever. Ambio 50:1774-1777. https://doi.org/10.1007/ s13280-020-01487-6

Forester J, McKibbon G (2020) Beyond blame: leadership, collaboration and compassion in the time of COVID-19. Socio Ecol Pract Res 2(3):205-216. https://doi.org/10.1007/ s42532-020-00057-0

Garstang M (2015) Elephant sense and sensibility: behavior and cognition. Academic Press, London, England

Gelfand MJ, Jackson JC, Pan X et al (2021) The relationship between cultural tightness-looseness and COVID-19 cases and deaths: a global analysis. Lancet Planet Health, 5: e135-44. https://www. thelancet.com/pdfs/journals/lanplh/PIIS2542-5196(20)30301-6. pdf

Gelfand MJ (2021) The threat reflex: why some societies respond to danger better than others. Foreign Affairs, 100(4):159+. https:// link.gale.com/apps/doc/A667436810/BIC?u=char69915\&sid= bookmark-BIC\&xid=30389aea

Gret-Regamey A, Huber SH, Huber R (2019) Actors' diversity and the resilience of social-ecological systems to global change. Nature Sustainability 2:290-297

Gunderson LH (2000) Ecological resilience-in theory and application. Annu Rev Ecol Syst 31:425-439

Holling CS (1973) Resilience and stability of ecological systems. Annu Rev Ecol Syst 4:1-23

Hu R (2020) Reinventing community in COVID 19: a case in Canberra. Australia Socio Ecol Pract Res 2(3):237-241. https://doi.org/10. 1007/s42532-020-00055-2

Jimenez S (2009) Compassion. In: Lopez SJ (ed) (2009) Encyclopedia of positive psychology. Wiley-Blackwell, Malden, pp 209-215

Keck M, Sakdapolrak P (2013) What is social resilience? Lessons Learned and Ways Forward Erdkunde 67(1):5-19

Kwok AH, Doyl EEH, Becker J et al (2016) What is "social resilience"? Perspectives of disaster researchers, emergency management practitioners, and policy makers in New Zealand. International Journal of Disaster Risk Reduction 19:197-211

Lyles W, White SS (2019) Who cares? J Am Plann Assoc 85(3):287300. https://doi.org/10.1080/01944363.2019.1612268
Lyles W, White SS, Lavelle BD (2018) The prospect of compassionate planning. J Plann Lit 33(3):247-266. https://doi.org/10.1177/ 0885412217735525

Meerow S, Newell JP, Stults M (2016) Defining urban resilience: a review. Landsc Urban Plan 147:38-49

Millennium Ecosystem Assessment (MA) (2005) Ecosystems and human well-being: synthesis. Island Press, Washington, DC. https://www.millenniumassessment.org/documents/document. 356.aspx.pdf. Accessed 1 Aug 2020

Morens DM, Taubenberger JK (2018) The mother of all pandemics is 100 years old (and going strong). American Journal of Public Health (AJPH) 108(11):1449-1454

Palko HC, Xiang W-N (2020) In fighting common threats, people's deep commitment to taking collective action matters: examples from China's COVID-19 battle and her other combats. Socio Ecol Pract Res 2(3):257-264. https://doi.org/10.1007/ s42532-020-00056-1

Romero-Lankao P, Gnatz DM, Wilhelmi O, Hayden M (2016) Urban sustainability and resilience: from theory to practice. Sustainability 8(12):1224. https://doi.org/10.3390/su8121224

Skaburskis A (2008) The origin of "wicked problems." Plan Theory Pract 9(2):277-280

Termeer CJAM, Dewulf A (2019) Biesbroek R (2019) A critical assessment of the wicked problem concept: relevance and usefulness for policy science and practice. Policy and Society. https://doi.org/10. 1080/14494035.2019.1617971

Tsui AS (2013) 2012 Presidential address: on compassion in scholarship: why should we care? Acad Manag Rev 38(2):167-180

Wang Y (2020) China's ongoing battle against the coronavirus: a scholar-practitioner's experiences and reflections. Socio Ecol Pract Res 2(2):181-183. https://doi.org/10.1007/ s42532-020-00047-2

Wu J, Wu T (2013) Ecological resilience as a foundation for urban design and sustainability. In: Pickett STA, Cadenasso ML, McGrath B (eds) Resilience in ecology and urban design: linking theory and practice for sustainable cities. Springer, pp 211-229

Xiang W-N (2019a) Ecopracticology: the study of socio-ecological practice. Socio Ecol Pract Res 1(1):7-14. https://doi.org/10.1007/ s42532-019-00006-6

Xiang W-N (2019b) Socio-Ecological Practice Research (SEPR): what does the journal have to offer? Socio Ecol Pract Res 1(1):1-5. https://doi.org/10.1007/s42532-018-0001-y

Xiang W-N (2020) Why does SEPR publish people's COVID-19 experience, observations, and reflections? Scio Ecol Pract Res 2(3):199-203. https://doi.org/10.1007/s42532-020-00066-Z

Xiang W-N (2021a) Seven approaches to research in socio-ecological practice \& five insights from the RWC-Schön-Stokes model. Socio Ecol Pract Res 3(1):71-88. https://doi.org/10.1007/ s42532-021-00073-8

Xiang W-N (2021b) COVID realities add support to inclusive cities. A blog for Springer Nature's "SDG 11 Sustainable Cities and Communities", https://www.springernature.com/gp/researchers/ sdg-programme/sdg11/socio-blog. Accessed 12 July 2021

Zheng C (2020) Caring for the self and others: a reflection on everyday commoning amid the COVID-19 pandemic. Scio Ecol Pract Res 2(3):243-251. https://doi.org/10.1007/s42532-020-00062-3 